\title{
Regional development planning and disparity in Bangladesh
}

\author{
Md. Mehedi Zaman Mithun \\ Department of Economics, University of Chittagong, Hathazari, Chittagong 4331, Bangladesh, \\ Email:mmzmithun@gmail.com
}

Accepted $27^{\text {th }}$ October, 2020

This study sheds some light on the regional development planning and regional disparity in Bangladesh and also analyzes spatial disparity of development through several factors to picturize the poverty situation in different regions of the country. In fact, this paper tries to represent the scenario of planning in microregional level. Findings from the paper reveal that, some regions of Bangladesh are still underdeveloped because of the fact that they continuously receive marginal share of public expenditure and national budget of the country. Gini Index for the total budget shows an incompatible level of income inequality to the people across various regions in Bangladesh. Northern and West regions of the country are mostly deprived of proper development planning and allocation of efficient budget. Overall, this article deeply provides a briefing for field people involved in regional planning processes in the rural areas. Bangladesh is yet to decentralize empirical power to the local government authority to ensure proper budget allocation and distribution. Allocation in ADP for health, education and agriculture sector should be enhanced urgently. Generating regional data will be much effective to fabricate more dynamic development planning and to understand the current situations of the lack-lusture regions of the country.

Key Words: Bangladesh, Development, Planning, Budget, Expenditure, Regions, Poverty

JEL Classification Codes O2, P4, O5, O22, O210, O180

\section{INTRODUCTION}

The idea of regional development originated with Joseph Stalin. Stalin wanted to develop each economic region in the Soviet Russia in such a way that in the event of an invasion, the occupation of any region by the capitalist powers might not cripple the economic power of the country. Bangladesh is a small country where regional disparities should not be so extreme. But Bangladesh is predominantly a rural country where over $80 \%$ of nation's 160 million people live in rural areas are mostly engaged in agriculture. That's why for balanced development of this country regional development planning is needed. By this planning, fullest development of the potentialities of the backward areas according to their capacity, so that the benefits of overall economic growth are shared by the inhabitants of these areas can be actualized. Urbanization program can be successful through this planning. While the government maintains and promotes urbanization and spatial development via allocation of resources slow rate of urbanization and wide spatial inequalities are well documented in this country. The regional development problems are not only multifaceted, they are complex and multidimensional in nature. No single discipline alone could tackle such intricate problems and need an interdisciplinary approach to analyze them, formulate development policies and programs and prepare rational plans and projects. The development problems vary from place to place, region to region and occur in space with varying degree of intensity and complexity. The problems necessarily could be effectively tackled by spatial planning process. The regional scientists are engaged in developing tools and techniques of analysis while regional planners based on such analysis formulate policies, put forward strategies and find desirable solution not only to tackle the present-day problems but also develop mechanism. This paper will try to examine the scenarios of regional planning in Bangladesh. That's why different types of data from different region are obtained from various sources.

\section{Literature review}

According to a report of World Bank (2002), eastern and western zonal partition of Bangladesh along the 
river Jamuna is quite eminent, therefore eastern divisions of Dhaka, Chittagong and Sylhet are comparatively growing better than the western divisions of Barishal, Khulna and Rajshahi. Khan and Mahmud (2018) explored that, a significant imbalance in development across regions in Bangladesh exists over the years which have resulted in spatial mutation of poverty incidences at regional level in this country. Hossain and Rahman (2012) revealed that, wide disparities exist in the level of development among different districts in Bangladesh. They also estimated the level of development among the regions with the help of composite index. Which was based on optimal combination of all development indicators like population, education, agriculture etc. There are various relevant studies which admit the regional diversifications in the socio-economic development of Bangladesh. Rahman (1994) tried to find the linkage between urbanization and rural development and recommended some policy implications. Sen and Ali (2005) conducted a study in this context and found that, the expansion of spatial inequality in social development diminished over the second half of the nineties although the level of disparity among regions of the country are still present. Moreover, static spatial disparity has been considered for both the cause and the effect of underdevelopment of the lagging regions in Bangladesh. Khan (2014) conducted a study to understand some realities for development planning in the context of Bangladesh. In his paper he tried to analyze the public expenditure pattern of the country by using Location Quotient (LQ) Analysis, Kuznets Ratio and Gini Index, This paper put some recommendations such as the western 3 divisions of Barisal, Khulna and Rajshahi should be given more attention in the distribution of budget to ensure fair supply of budget for development programs. He commented, these divisions quite lagged behind in terms of allocation of budget. He also proposed to open special programs relating to poverty reduction in the forms of social safety net distribution in the districts of these divisions. Which may reduce the development gap with the other developed divisions of the country. Rahman and Hossain (2009) led a study to reveal the convergence of per capita income situation in various divisions of Bangladesh. He found that, proper attention in terms of providing financial, technological and infrastructural supports to the lagging divisions should intensified. In this regard, he also said that that the existing strategy of pro-poor growth might be an effective way to accelerate per capital income convergence within regions in Bangladesh. Balisacan and Fuwa (2003) tried to figure out whether spatial disparity is increasing in Philippines. Their research was related to national income level disparity to spatial inequality. Regional disparities in the availability and the range of available qualities in 17 of goods and services in developing countries was the main concern in the work of Banerji and Jain (2003). In their paper they argued that, if there remains economies of scale in the production of a particular quality of good, then market thickness might play a vital 012

E3 J. Bus. Manage. Econ. role in determining the range of available qualities of the good. Tadjeoddin, Suharyo and Mishra (2003) explored regional disparity and central-regional conflict in the context of Indonesia. Miemyk, Bonner, Chapman and Shellhammer (1967) tried to identify and to measure unerringly as possible, the inter-relationships that existed in a single local economy of Boulder, Colorado, USA. They recommended that, the methods developed for measuring local income and employment impacts in Boulder economy can be applied in a large scale at anywhere.

\section{Regional Development Planning}

Regional Development planning is a category of planning and development that deals with designing and placing infrastructure and other elements across a large area. Planning zones may include several towns, cities and even parts of different states or regions, each of which could have its own 'Urban Planning' office or there may have any 'Planning Commission' structured for implementation of various development plans and projects. The key to urban regional planning is anticipating the needs of a community or group of communities before those needs arise. Experts in this field might try to predict how and where the population of a region is going to grow over the next decade and recommend to spend more public budget and building more roads and other infrastructure to support that growth before it happens.

\section{Development Planning Strategy in Bangladesh}

In developing economies like Bangladesh, growth with equity and social justice remains the overarching goal of our development strategy. Since the independence, real per capita income of Bangladesh has increased by more than 4 fold, poverty reduced by more than one third and the country is well set to achieve most of the Sustainable Development Goals. Foundation of development activities are based on Bangladesh State Constitution, Development Planning, MDGs and SDGs. Accordingly, between FY1973 and FY2015 there have 6 successive Five Year Plans and an interim Two Year Plan (1979-80) were implemented in Bangladeshm (See table 1).

The purpose of regional planning in Bangladesh is to reduce poverty, income inequalities and regional imbalances in development. Regional planning in its true perspective, tends to be much more responsive to the emerging socio-economic countries at various territorial levels. Development philosophy of the country may include the factors below.

\section{Decrement of regional imbalance in development.}

Explore inclusive growth strategy. Specifically the aim is to reduce poverty and income inequality by ensuring 
Table 1. Economic Plans of Bangladesh

\begin{tabular}{lcc}
\hline \multirow{2}{*}{ Plans } & \multicolumn{2}{c}{ Annual Average Growth } \\
\cline { 2 - 3 } & Target & Actual \\
\hline First Five Year Plan (FY73-FY78) & 5.5 & 4 \\
Two Year Plan (FY78-80) & 5.6 & 3.5 \\
Second Five Year Plan (FY80-FY85) & 5.4 & 3.8 \\
Third Five Year Plan (FY85-FY90) & 5.4 & 3.8 \\
Fourth Five Year Plan (FY90-FY95) & 5 & 4.2 \\
Fifth Five Year Plan (FY97-FY02) & 7 & 5.1 \\
FY02-FY06 & & 5.5 \\
FY06-FY10 & & 6.3 \\
Sixth Five Year Plan (FY11-FY15) & 8 & 6.5 \\
\hline
\end{tabular}

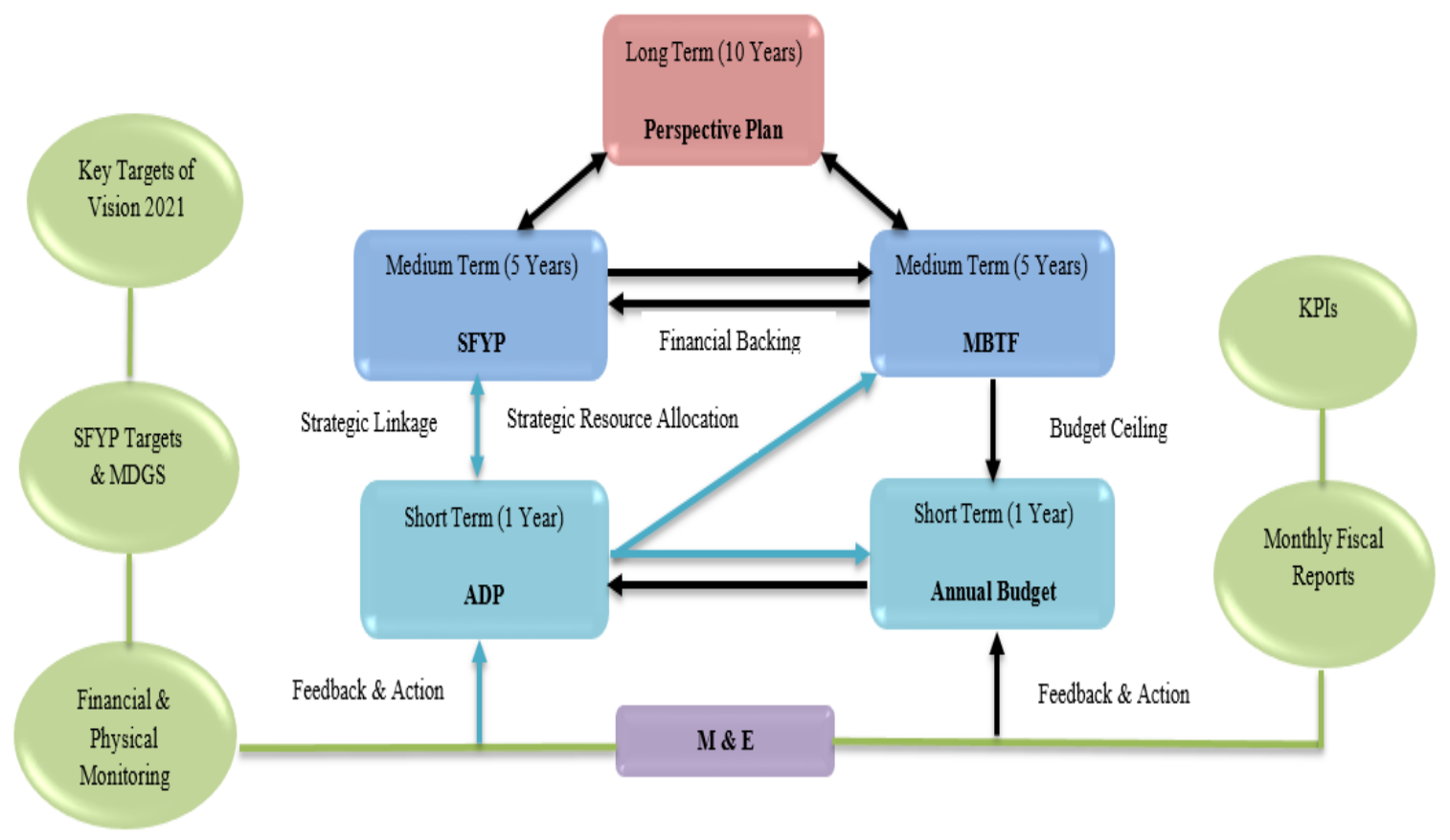

Figure 1: Budgetary and Planning Management System for Territorial Plans in Bangladesh. Note: ADP=Annual Development Program; KPI= Key Performance Indicator; MBTF= Medium-Term Budgetary Framework; $M D G=$ Millennium Development Goal; M \& E= Monitoring and Evaluation; SFYP= Sixth Five Year Plan

participation of the poor people to economic resources and employment.

\section{Raising participation of Women in economic activities.}

The overarching vision of the perspective development plan is to accelerate national and regional development process. It conceived equitable and smooth growth process where poverty will be at its lowest level and regional development will be balanced. The fundamental objective of the Plan (See figure 1) is to achieve middle income country status in real terms by
2021- the $50^{\text {th }}$ anniversary of the nation and golden jubilee year of national independence.

Bangladesh government has formulated the first ever long-term "Perspective Plan 2010-2021" in 2010 adopting the Vision of building a happy and prosperous nation by 2021. The main objectives of the Perspective Plan are: To achieve and sustain an annual GDP growth rate of $10 \%$ by 2021 .Raising per capita income to US \$2000.Expanding and diversifying the industrial sector to increase its contribution to GDP to $40 \%$.Reduction of unemployment rate to $15 \%$. Decrease in the number of people under poverty line from $31.5 \%$ to $15 \%$. Fully eradicate illiteracy as soon as 
possible after 2014. To ensure per capita energy consumption at $600 \mathrm{KWh}$.

Strengthening information technology to build digital Bangladesh. The principal goal of the strategies taken by Bangladesh government is to reduce poverty which will gradually lift the huge portion of the people above the poverty line and improve their standard of life. Bangladesh Government is committed to achieve the criterions of SDGs and integrated these international and regional commitments in the Seventh Five Year Plan. Bangladesh has already met maximum targets of MDG. Alongside, the government also implemented the Poverty Reduction Strategy Paper (PRSP-I, 2003-08 and NSAPR II, 2009-2011), The Long Term Perspective Plan (2010-2021) and the Seventh Five Year Plan (2016 - 2020).

\section{Purposes of Regional Planning in Bangladesh}

\section{Infrastructure Development}

Infrastructure refers to systems, structures and facilities serving the economy of a country, city, town commodities and services essential to sustain or enhance societal living conditions. Infrastructure may be owned and regulated by governments and by private companies such as public utility or railway companies. Generally most roads, water distribution system, major ports and airports, and sewage networks are publicly owned. Whereas most energy, telecommunication, connectivity networks are privately owned. Bangladesh, with its vision to become a middle income country by 2021 , has been waiting for prescient actions to control an economic recovery for continuation of economic progress. Bangladesh has been showing strong growth performance with a GDP growth of $6-7 \%$. The economy however has to deal with a number of economic bottlenecks to reach the required GDP growth rate of 8$10 \%$ to fulfill 'Vision 2021'. In order to prioritize large scale infrastructure, communication and power projects, right after formation of government in January 2014, some projects were taken for improvising the socio-economic structure of the lagging regions of country and to decentralize the economic hubs. So that the peoples from the lagging regions can uplift their economic conditions. Some remarkable projects running on priority basis are Padma Bridge Project, Padma Rail Link project, Metro Rail Project, Karnaphuli Tunnel Project, Payra Deep Sea Port or area, business or industry including the services and facilities necessary for its economy to the country. Currently 10 mega projects are running to enhance the infrastructural strength of the function. Infrastructure can be defined as 'the physical component of interrelated systems providing Project etc. People from the most deprived regions of the country will mostly benefitted after completion of these mega projects. As an example 'Padma Bridge' is the country's largest will directly served by it. When the bridge comes into operation it is estimated that it will boost the infrastructural undertaking so far. More than 19 southwestern districts which are most unprivileged GDP growth by $1.23 \%$. The cost-benefit ratio of Padma Bridge is very high. The increased connectivity with this bridge will function as a linkage between the backward regions with rest of the country. It will boost the growth of the agriculture and industry sector in those areas. It will also directly connect the second most important port of the country named Mongla and industrial zone in Khulna with the main part of the country. Padma Bridge will also connect the country to Asian Highway and trans-Asian railway. That's why besides the infrastructural revolution, regional development planning is also much important to savouring these benefits fully.

\section{Empowerment of Local Government}

Local government in Bangladesh provide essential services to meet the diverse need of their residents and to drive progress on many development measures. Local Government functions as the linkage between rural people with the policymakers of the country. But most local government leaders in Bangladesh are not fully empowered to carry out their work. Few are supported by the scarce pool of qualified professionals who can plan and implement essential services. Management systems are typically weak and broad based. Community participation in local government decision making is usually limited. Policymakers should take necessary steps to strengthen the structure of local government and to ease the administrative works in the local level, so that Division, District, Upozilla, Union and Word based regional development planning may work smoothly. That will reach the benefits to the people from root level and enhance the economic development process of the country.

\section{Decentralization of Economic Activities to Discourage the Migration Trend}

Bangladesh is governed by the parliamentary form of government. The Prime Minister acts as the chief executive of the country. For the convenience administration the country is divided into six administrative divisions each placed under a divisional commissioner. Every division has sub divided into district. And these districts consist of several Upozillas. There are two types of local government institutions exist in Bangladesh- i) Rural ii) Urban. The government has a council of ministers. Now the administrative structure of the country is as shown in table 2 . In the third world countries decentralization is identified as transfer of authority from center to agencies, institutions or person working at the periphery for planning, decision making and performing other administrative works. The and of Bangladesh provides that the local government in a very administrative unit of the republic should be entrusted to bodies composed of persons 
Table 2. Local Administrative Structure of Bangladesh

\begin{tabular}{lc}
\hline Administrative Units & Numbers \\
\hline Division & 8 \\
District & 64 \\
Upozilla & 492 \\
Union & 4571 \\
Village & 85000 \\
\hline
\end{tabular}

elected in accordance with laws. Decentralization practice in Bangladesh involves four dimensions. Decentralization in Bangladesh is a mixture of administrative, fiscal, economic and political functions and relationships. The main problems of local government are many. Such as frequent changes in the local government structure with the change of political power at the national level, predominance of government officials, inadequate mobilization of local resources, misuse and misappropriation of development fund and absence of rural people's participation in the development projects undertaken by the local government bodies. The above problems are not only for Bangladesh. The problems, however may be minimized if a stable and sound local

government system is established. In view of above observation some recommendations can conclude as the following policy measures: Ensure Constitutional stability. Maintenance of stable political process. Constitution Amplifying local government efficiency.

Information, monitoring and evaluation. Local technical and managerial capacity Civil service and decentralization. Role of civil society.Local participation can motivate strongly for change. Accountability and transparency in official works. Promoting egovernance. Without a long form vision and a consistent government policy the attempts to restructure and strengthen the local government system is bound to end in failure. By taking proper moves and strengthen the structure of local economy, government can discourage people to migrate to the major urban areas. At present no absolute democratic decentralization is found in Bangladesh, rather there is administrative decentralization instead. It is desirable that if the government of concern authority follow the above suggested measures for implementation of decentralization policy in the near future this should be transformed into democratic decentralization so that the local government can operate without interference from the central government.

\section{Regional Variation of Budget Distribution in Bangladesh}

It is an irony that, spatial variation persists across regions within Bangladesh in terms of distribution of budget. Though homogeneous distribution of budget is not practically possible in current socio-economic reality, sharp variation in budget distribution is a hindrance to the balanced development of the country. Following section describes the regional variation of budget distribution. District data regarding distribution of development Budget (ADP) among various districts from Fiscal year 2006-07 to 2008-09 (up to March) have been used for measuring the regional variation across Bangladesh. More recent data at regional level are quite not available for analysis. As Rangpur Division has been introduced in 2010, six divisions have been used to analyze the divisional variation of budget allocation within the study period.

\section{Regional Variations in Development Budget}

Regional disparity regarding the distribution of annual development plan is quite prominent over the years. Table 3 below represents a comparative picture of Development Expenditure across various regions of the country. According to the statistics of Finance Ministry, during the Fiscal year 2008-09 Dhaka division got the highest allocation of ADP totaling 6263 crore taka followed by Chattogram (4970 Cr. TK), Rajshahi (4354) respectively. Lowest ranked district in terms of ADP allocation within this period year was Sylhet having only $1517 \mathrm{Cr}$. Tk. But in the parameter of per capita expenditure, Sylhet division got the highest allocation of 1.76 thousand taka and Rajshahi division got the lowest of 1.33thousnd taka per capita.

\section{Regional Variations in Non-Development Budget}

Non-development budget also maintains a sequence regarding to development expenditure. The table 4 below shows a glimpse of that statistic. According to the statistics of Finance Ministry, during the Fiscal year 2008-09 Dhaka division got the highest allocation of ADP for non-development expenditure totaling 26502 crore taka followed by Chattogram (11051 Cr. TK), Rajshahi (15864) respectively. Lowest ranked district in terms of ADP allocation within this period year was Sylhet having only $2697 \mathrm{Cr}$. Tk. Also in the parameter of per capita expenditure Dhaka division got the highest allocation of per capita non-development budget totaling 6.27 thousand taka and Sylhet division got the lowest of 3.14 thousand taka. 
Table 3. Comparative Statement of Development Expenditure (Taka in Thousand)

\begin{tabular}{llll}
\hline \multirow{2}{*}{ Division } & Population & \multicolumn{2}{c}{ Development Expenditure } \\
\cline { 3 - 4 } & & Actual & Per Capita \\
\hline Dhaka & 42895479 & 62633049 & 1.483 \\
Chattogram & 26686009 & 49706176 & 1.892 \\
Rajshahi & 33180515 & 43548540 & 1.333 \\
Khulna & 16155524 & 21975369 & 1.382 \\
Barisal & 8979846 & 17152364 & 1.94 \\
Sylhet & 8722356 & 15179641 & 1.768 \\
\hline
\end{tabular}

Table 4. Comparative Statement of non-development expenditure (Taka in Thousand)

\begin{tabular}{llll}
\hline \multirow{2}{*}{ Division } & Population & \multicolumn{2}{l}{ Non-Development Expenditure } \\
\cline { 3 - 4 } & & Actual & Per Capita \\
\hline Dhaka & 42895479 & 265029365 & 6.276 \\
Chattogram & 26686009 & 110517986 & 4.207 \\
Rajshahi & 33180515 & 158647075 & 4.857 \\
Khulna & 16155524 & 67753122 & 4.26 \\
Barisal & 8979846 & 32837342 & 3.715 \\
Sylhet & 8722356 & 26977999 & 3.142 \\
\hline
\end{tabular}

Table 5. Consolidate Fund Expenditure [Non-Development \& Development] (Taka in Thousand)

\begin{tabular}{llll}
\hline Division & Population & Actual & Per Capita \\
\hline Chattogram & 25862304 & 160224162 & 6.195 \\
Rajshahi & 32156347 & 202195614 & 6.288 \\
Khulna & 15656858 & 89728491 & 5.731 \\
Barisal & 8702669 & 49989705 & 5.744 \\
Sylhet & 8453127 & 42157640 & 4.987 \\
\hline
\end{tabular}

\section{Consolidate Comparative Statement of Per Capita Expenditure}

Table 5 shows the consolidate expenditure for the fiscal year of 2008-09 among the divisions of the country. Dhaka division got almost double fund expenditure than the business capital division Chattogram. Dhaka division also stands first on per capita fund expenditure. The table also reflects, on both of actual and per capita parameter Sylhet division has the lowest fund expenditure. Figures 2 and 3 below represent a comparative picture of consolidate expenditure and the percentage of aggregate budget expenditure respectively for the fiscal year of 2008-09 among the divisions of the country.

\section{Spatial Disparity of Development among Various Regions in Bangladesh}

\section{Gini Index and Kuznets Ratio}

Spatial variation in budget allocation insists in regional level in Bangladesh. Gini Index represents the measurement of income distribution of a Country, which value ranges between 0 and 1 . The value 0 represents perfect equality and 1 represents perfect inequality. For Bangladesh, during the fiscal year 2006-07 and 200809 (upto march), Gini index value has been found 0.34 for total budget of the country. Whereas the Gini value of ADP for the same time period is calculated 0.27 . 


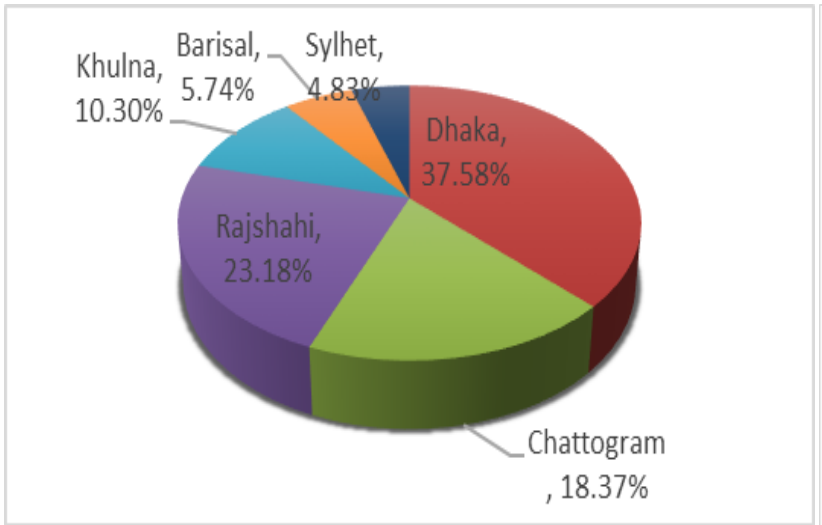

Figure 2. Comparative picture of Fund Expenditure among the divisions

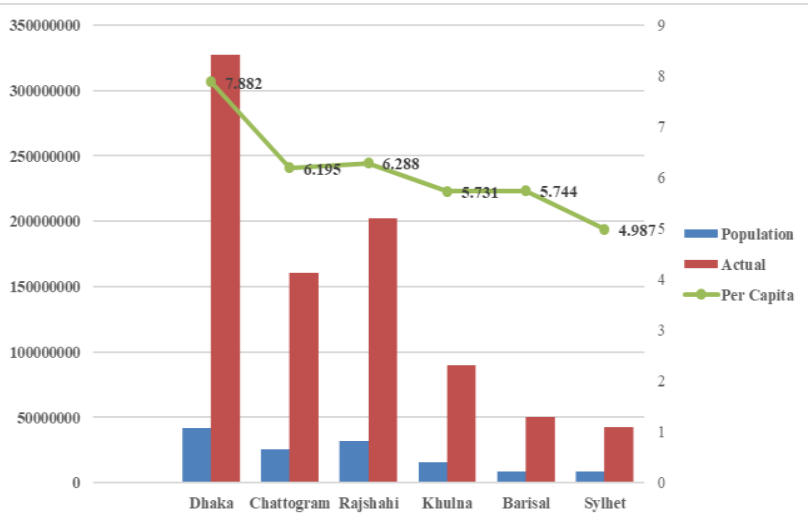

Figure 3. Aggregate Budget Expenditure by Divisions

Table 6. Spatial Disparity of Development among Various Regions in Bangladesh

\begin{tabular}{lccc}
\hline $\begin{array}{l}\text { From 2006-07 to 2008- } \\
\text { 09 [Upto March] } \\
\text { (Values in crore taka) }\end{array}$ & ADP & Non-Development & Total Budget \\
\hline Top 20\% & 21520 & 85650 & 105780 \\
Bottom 40\% & 9870 & 24520 & 36200 \\
Kuznets Ratio & 2.2 & 3.5 & 2.9 \\
\hline
\end{tabular}

However, for non-development expenditure across the country the Gini value is 0.38 . Which shows that some specific regions are getting more allocation of budget due to some socio-administrative criterion than other parts of Bangladesh. 'Kuznets ratio' is the ratio of the incomes received by top $20 \%$ and bottom $40 \%$ of the country's total population (See table 6). It is used to measure the degree of inequality between higher and lower income groups of a country. Kuznets ratio reflects share distribution of income in different regions of the country. During fiscal year 2006-07 and 2008-09 (upto march), Kuznets ratios are 2.05 for the ADP distribution, 3.5 for the non-development expenditure and 2.9 for aggregate budget expenditure respectively. Which reflects that, disparity exists across various regions of Bangladesh in terms of allocation of public money in the form of budget distribution.

\section{Nominal Household Income in Various Regions}

Disparity is also apparent on nominal household income among the regions of Bangladesh. Table 7 below provides monthly household nominal income, expenditure and consumption expenditure statistics in the administrative divisions obtained from Household Income and Expenditure Survey (HIES)-2010. The highest average monthly household nominal income was recorded for Chattogram Division at 14092 taka, followed by Dhaka Division at 13226 taka and Sylhet Division at 11629 taka. All of these values exceeded the national average of 11479 taka in 2010 . The other four Divisions were recorded monthly household income below the national average. Where in Barishal Division at 9158 taka, in Khulna Division at 9569 taka and in Rajshahi Division at 9342 taka and in Rangpur Division at 8359 taka. The highest average monthly consumption expenditure was filed in Chattogram Division at 14360 taka followed by Sylhet Division at 12003 taka and Dhaka Division at 11643 taka. All the consumption expenditure values exceeded the national average of monthly household consumption expenditure at 11003 taka in 2010. On the other hand, the average monthly household expenditure of Barishal, Khulna, Rajshahi and Rangpur Divisions fell below the national average level and were estimated at 9826 taka, 9304 taka, 9254 taka and 8298 taka respectively.

\section{Regional Comparison of Road Infrastructure and Electricity Distribution}

Infrastructure is crucial to promote socio-economic progress of a region. Here, two important infrastructure indicators namely (i) Percentage of paved road to total road and (ii) Percentage distribution of household electricity have been used to assess the status of infrastructure across the district of Bangladesh. List of 10 most deprived districts in terms of the two infrastructure indicators are provided in table 8 below. 
Table 7. Monthly Household Nominal Incomes and Consumption Expenditures by Divisions

\begin{tabular}{lll}
\hline Division & Income & Consumption Expenditure \\
\hline Barishal & 9158 & 9826 \\
Chattogram & 14092 & 14360 \\
Dhaka & 13226 & 11643 \\
Khulna & 9569 & 9304 \\
Rajshahi & 9342 & 9254 \\
Rangpur & 8359 & 8298 \\
Sylhet & 11629 & 12003 \\
\hline
\end{tabular}

Table 8. Regional Comparison of Roads Infrastructure and Electricity

\begin{tabular}{llllll}
\hline Rank & Districs & $\begin{array}{l}\text { Percentage of } \\
\text { Paved Road to } \\
\text { Total Road }\end{array}$ & Rank & District & $\begin{array}{l}\text { Percentage } \\
\text { Distribution of } \\
\text { Household Electricity }\end{array}$ \\
\hline 1 & Rangamati & $60.88 \%$ & 1 & Lalmonirhat & $18.10 \%$ \\
2 & Bandorban & $61.30 \%$ & 2 & Kurigram & $21.48 \%$ \\
3 & Sunamganj & $64.76 \%$ & 3 & Sunamganj & $29.57 \%$ \\
4 & Netrokona & $79.26 \%$ & 4 & Gaibandha & $32.72 \%$ \\
5 & Bagerhat & $80.91 \%$ & 5 & Barguna & $33.05 \%$ \\
6 & Cox's Bazar & $81.58 \%$ & 6 & Panchagar & $34.09 \%$ \\
7 & Chattogram & $83.05 \%$ & 7 & Nilphamari & $34.90 \%$ \\
8 & Barishal & $88.10 \%$ & 8 & Jamalpur & $36.47 \%$ \\
9 & Sylhet & $89.90 \%$ & 9 & Patuakhali & $36.52 \%$ \\
10 & Khulna & $90.65 \%$ & 10 & Thakurgaon & $38.55 \%$ \\
\hline
\end{tabular}

\section{Divisional Variation in Types of School Attended}

To understand the educational diversification among various region, the types of schools as a basic mode of educational institution in the administrative divisions of the country are well differentiated here, according to the Household Income and Expenditure Survey (HIES)2010 report. The number of government operated schools was the highest at in Barisal division at $85.00 \%$ and lowest in Sylhet division at $75.15 \%$. The proportion of government subsidized school was the highest at $17.00 \%$ in Sylhet division and the lowest at $8.58 \%$ in Barisal division. The percentage of non-subsidized schools was the highest in Dhaka division at $2.20 \%$ and the lowest in Barisal division at $0.27 \%$. Alongside the percentage of NGO run schools was the highest at $3.88 \%$ in Rajshahi division and lowest at $1.15 \%$ in Rangpur division. The percentage of recognized Madrashas was the highest at $3.00 \%$ in Barisal division and lowest at $0.82 \%$ in Khulna division.

\section{Poverty Alleviation in Bangladesh}

Rapid growth process enabled Bangladesh to fulfill the criterion of lower middle-income country in 2015. In 2018, Bangladesh fulfilled the criterion for graduation from United Nation's Least Developed Countries (LDC) and is on the right track for graduation to a middleincome country by 2024 (Bangladesh overview- World Bank, 2019). The head count ratio of incidence of poverty in eight administrative divisions of the country using Cost of Basic Needs (CBN) method is described in figure 4. Bangladesh has achieved remarkable progress in poverty alleviation during last few years as a result of the consecutive endless endeavor of the government. Not only the rate of poverty has decreased, but also the incidence and depth of poverty has been reducing in regular basis all over the country. Because of efficient depiction of different government and non-government development projects, poverty rate declined $15.7 \%$ within a decade $(40 \%$ in 2005 to $24.3 \%$ in 2016). According to the $7^{\text {th }}$ Five Year Plan (2016-2020) by 2020, the government has targeted to reduce poverty rate at $18.6 \%$. Two top divisions have higher incidence poverty are Rangpur and Mymensingh. Rangpur division has the highest incidence of poverty (HCR) at $47.2 \%$, followed by Mymensingh division at $32.8 \%$. On the other hand, Rajshahi division at $28.9 \%$ Barisal division at $26.5 \%$ and Khulna division at $27.5 \%$. Dhaka division has the lowest incidence of poverty (HCR) of $16 \%$ preceded by Sylhet division with HCR of $16.2 \%$ and Chattogram division with HCR of $18.4 \%$. Incidence of poverty has 


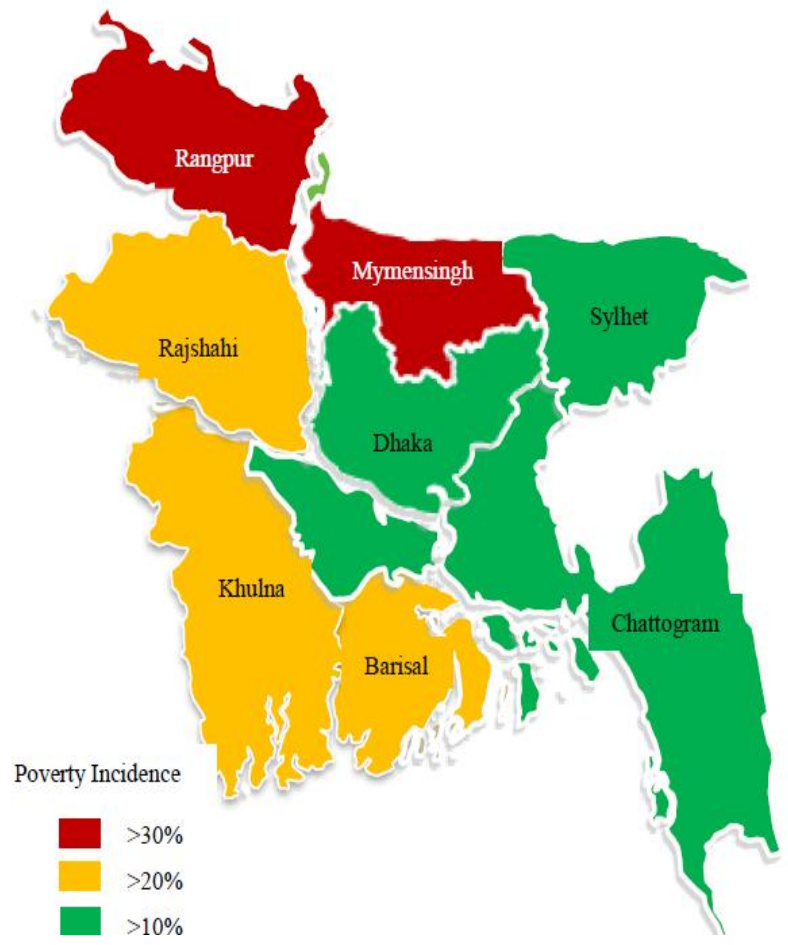

Figure 4. Comparison of Division wise Incidence of Poverty (Using Upper Poverty Line)

significantly deducted in Dhaka division compared to other divisions of the country. The deduction rate is almost half (16\% in 2016 from $30.5 \%$ in 2010 ). Urban poverty increased in 2016 in Rangpur, Sylhet and Chattogram division compared to 2010. However, overall poverty in Rangpur division increased in 2016. But in Sylhet and Chattogram division both overall and rural poverty was decreased. The government has fixed up the target to reduce poverty rate at $9.7 \%$ and malnutrition rate less than $10 \%$ by 2030 . For that purpose government is running some effective programs all over the country such as VGF, VGD, GR, TR, OMS, old age allowance, allowance for the financially insolvent disabled, stipend for the disabled students, allowance program for widow, deserted women, honorarium and medical allowance for injured freedom fighters, maternity allowance for poor mother, livelihood improvement of tea garden labors, ashrayan projects, grihayan tahabil, ekti bari ekti khamar project etc.

\section{Conclusion and Policy Recommendations for Development Planning in Bangladesh}

This paper has discussed on some facts about regional development planning and allocation of public expenditure in the context of Bangladesh. Several major conclusions can be drawn from the above discussion as follows: Regional development planning framework in Bangladesh seems to be very cranky.
Some regions of Bangladesh are still underdeveloped because of the fact that they continuously receive marginal share of public expenditure and national budget of the country.

Gini Index for the total budget shows an incompatible level of income inequality to the people across various regions of the country. Northern and West region of the country are mostly deprived of proper development planning and allocation of efficient budget. Poverty alleviation is taking too much time in the north-west part of the country. Dealing with such poor areas which can be explained as "poverty pockets" are the nation's current challenge. Bangladesh is yet to decentralize empirical power to the local government authority to make proper budget allocation and distribution.

Development budget is still insufficient to make any proper plan for the lagging regions of the country.

Implementation of ADP largely depends on the Executing Agencies and Administrative Ministries. Planning Commission only facilitates the implementation process.Proper development planning especially for the lagging regions should be an urgently needed agenda for balanced and homogeneous development of Bangladesh. Regional disparity across the country would have made the overall socioeconomic development wonky in long term. Here are some policy recommendations from the study above can be made as follows: Capacities and participation on development and planning of the implementing administrations must be improved for utilizing project aid and to reduce pressure on domestic resources. 
Private sector led development planning should give more concern to implement more projects. Under Public-Private Partnership (PPP) more projects should be implicated. More roads and other physical infrastructures should built to connect the remote regions of the country with the major cities. This will help to decentralize the socio-economic facilities and to abate rising pressure on the capital .The ultimate goal of public investment should decrease poverty gap as well as infrastructural gap especially in roads, ports, bridges, energy sectors.

Government should give more concern to improve subsidiary facilities to gear up industrialization and to decentralize it especially in the lagging regions of the country. It will create more employment and improved socio-economic condition of the remote regions will lead the macroeconomic variables to elevate.Building social awareness by educating people through setting up more educational institutions and running subsidiary programs to save poor students from dropout will improve the socio-economic condition of the poor regions of the country. In recent years, allocation to the health, education and agricultural Sector has reduced in this country in terms of percentage share of ADP. As a large share of the population lies below the poverty line and still near about $50 \%$ of people directly or indirectly dependent on agriculture; allocation for health, education and agriculture sector should be health condition of the deprived people in these regions. Capacity development of officials related to appraisal, formulation and assessment in the enhanced urgently. Government can attach NGOs to enhance social, economic, educational and regional level are also essentially required.

Projects or programs should be consistent with the plan objectives and targets.

Generating regional data will be much effective to fabricate more dynamic development planning and to understand the current situations of the lack-lusture regions of the country.

\section{Limitations of the Study}

Regional data are still not available or easily reachable in Bangladesh because regional considerations do not get priority in development planning of this country. Unavailability of proper data and data sources are the main obstacles to structuralize the development planning framework of this country. It is hoped that, on the condition of availability further researches in this study area by using more updated data will give more transparent image of the regional development planning condition of the country.

\section{References}

Ali Z, Sen B (2003). Spatial Inequality in Social Progress in Bangladesh. Programme for Research on Chronic Poverty in Bangladesh (PRCPB), Bangladesh Institute of Development Studies, Dhaka. PRCPB Working Paper No. 7
Amin MSR, Tamima MU (2008). Regional divergence of income and allocation of public facilities in Bangladesh. Bangladesh Res. Pub. J. 1(1): Page 22-37.

Anam M (2016). Padma Bridge- New Lifeline of Development. The Daily Star, January 18, 2016.

An Overview of Spatial Policy in Asian and European Countries. Ministry of Land, Infrastructure, Transport and Tourism, Japan (MLIT). Retrieved from: https://www.mlit.go.jp/kokudokeikaku/international/spw/general/ban gladesh/index_e.html

BBS (1992-2017). Statistical Yearbook of Bangladesh. Bangladesh Bureau of Statistics, Ministry of Planning, Government of Bangladesh, Dhaka. Retrieved from: http://www.bbs.gov.bd/site/page/29855dc1-f2b4-4dc0-9073f692361112da/Statistical-Yearbook

Bangladesh Economic Review (2005-2018). Economic Adviser's Wing, Finance Division, Ministry of Finance Government of the People's Republic of Bangladesh, December 2018. Retrieved from: https://mof.portal.gov.bd/site/page/28ba57f5-59ff-4426-970abf014242179e/Bangladesh-Economic-Review

Carter B (2013). Microcredit for the ultra-poor. Evidence on Microcredit for the Ultra-Poor (GSDRC Helpdesk Research Report), Birmingham, UK: Governance and Social Development Resource Centre, University of Birmingham.

Chand M, Puri VK (1983). Regional planning in India. Allied publications Private Limited, New Delhi. Available at: https://books.google.co.in/books?id=6-sPBAAAQBAJ

HIES (2010). Household Income and Expenditure Survey. Bangladesh Bureaus of Statistics, Ministry of Planning, Dhaka. Retrieved from: http://203.112.218.65:8008/WebTestApplication/userfiles/Image/La testReports/HIES-10.pdf

Hossain A (2006). Growth and Convergence of Per Capita Output Levels across Regions of Bangladesh, 1982-97, Economic Analyses of Contemporary Issues in Bangladesh, The University Press Limited (UPL), Chap.3, pp.75-93.

Khan AM (2014). Allocation of Public Expenditure: Some Realities for Development Planning in Bangladesh. J. Bangladesh. Institute. Planners. 7: 1-15.

Khan AM, Jobaid M (2018). Development Budget in Bangladesh: Spatial Analysis of Regional Dynamics. J. Bangladesh. Institute. Planners. 11(Printed in June 2020): 39-54.

Misra RP, Urs DV, Natraj VK (1978). Regional planning and national development. In Asian Symposium on Regional Planning and National Development 1974: Mysore). Vikas Pub. House.

Mithun MMZ (2020). Road Transportation Infrastructure, Industrial Evolution and Economic Growth. Intl. J. Sci. Technol. Res. 9(6): 664-673.

Jhingan ML (2007). The Economics of development and planning, 39th edition. Vrinda Publications (P) Ltd., Page no: 726.

Muhith AMA (2012). Three Years of Development: Pathway of Future. Budget Speech 2012-13, Ministry of Finance, Government of People's Republic of Bangladesh, Dhaka, Bangladesh. Retrieved from: https://mof.gov.bd/

PKSF (2003). Sustainable Transformation out of Extreme PovertyThe Prime Way. Palli Karma Sahayak Foundation, Dhaka. Retrieved $\quad$ From: https://pksf-bd.org/web/wpcontent/uploads/2014/05/Sustainable-Transformation-out-ofExtreme-Poverty-The-PRIME-Way.pdf

Planning Commission (2011). Sixth Five Year Plan FY 2011 - FY 2015, Accelerating Growth \& Reducing Poverty, Part 3: Statistical Annex and Technical Framework. General Economics Division, Planning Commission, Government of People's Republic of Bangladesh, Dhaka, Bangladesh. . International Monetary Fund Washington, D.C., IMF Country Report No. 13/63

PRSP (2005). National Strategy for Accelerated Poverty Reduction. General Economics Division, Planning Commission, Government of Bangladesh. International Monetary Fund, Washington D. C., IMF Country Report No. 05/410

Rahman (2006). Financial Development and Income Convergence: A Panel Data Approach. Economic Analyses of Contemporary Issues in Bangladesh, The University Press Limited (UPL), Chap.3, pp.7593.

Rahman MH, Hossain MS (2009). Convergence in per capita income across regions in Bangladesh. The Bangladesh Develop. Studies. 32(1): 45-60. 
Todaro MA, Smith SC (2008). Economic Development. 10th Edition, Addison-Wesley Longman, Inc. Available at: https://www.textbooks.com/Economic-Development-10thEdition/9780321485731/Michael-P-Todaro-and-Stephen-CSmith.php
World Bank (2013). Bangladesh Poverty Assessment: Assessing a Decade of Progress in Reducing Poverty, 2000-2010. A joint report of the Human Development \& Poverty Reduction and Economic Management Sectors South Asia Region, World Bank, Dhaka. Bangladesh Development Series Paper No. 31. 